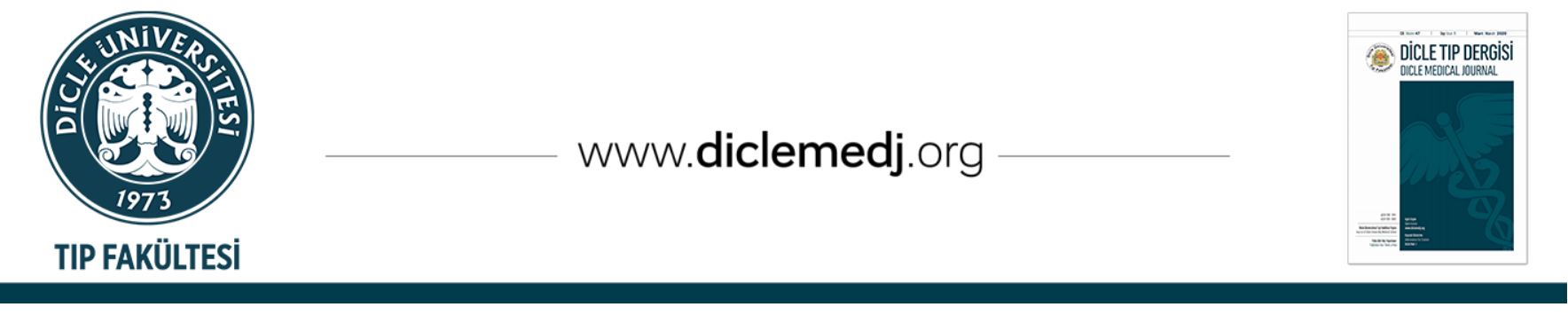

Derleme / Review

\title{
SARS-CoV-2 ile İlișkili Akut Böbrek Hasarı
}

\author{
Dede Şit iD 1 , Hasan Kayabaşı ${ }^{\text {iD } 1}$ \\ 1 Sağlık Bilimleri Üniversitesi Hamidiye Tıp Fakültesi Ümraniye Eğitim ve Araştırma Hastanesi Nefroloji Kliniği İstanbul, Türkiye
}

Geliş: 20.05.2020; Revizyon: 10.06.2020; Kabul Tarihi: 12.06.2020

Öz

2019 yılının sonunda Çin'de patlak veren yeni tip koronavirüs (COVID-19) çok kısa sürede küresel bir salgın halini aldı. COVID-19 infeksiyonu esas olarak solunum sistemini etkilemekle birlikte, şiddetli akciğer tutulumu olan olgularda ileri yaş, diyabet, hipertansiyon, kardiyovasküler hastalık, kronik böbrek hastalığı (KBH) gibi yüksek risk grubundaki hastalarda böbrek tutulumu sık görülmektedir. Akut böbrek hasarı (ABH), COVID-19 infeksiyonunun majör komplikasyonlarından biridir, KBH olanlarda daha sık görülmektedir ve artmış morbidite ve mortalite ile ilişkilidir. ABH gelişen olgularda kalıcı böbrek hasarı riski artmıștır. Özellikle COVID-19 infeksiyonu sırasında böbrek fonksiyonlarının dikkatle kontrol edilmesi ve süreç içinde yakın izlem gerektiği, halen etkin bir tedavisi olmayan bu pandemik infeksiyon için yaşamsal önemdedir. Bu derlemede COVID-19 seyri sırasında gelişebilecek böbrek tutulumu ve akut böbrek hasarı tartışılmıştır.

Anahtar Kelimeler: COVID-19, akut böbrek hasarı, böbrek fonksiyonları.

DOI: $10.5798 /$ dicletip.755786

Correspondence / Yazışma Adresi: Dede Şit, Sağlık Bilimleri Üniversitesi Hamidiye Tıp Fakültesi Ümraniye Eğitim ve Araștırma Hastanesi Nefroloji Kliniği Elmalıkent Mah. Adem Yavuz Cad. No: 1 (34764) Ümraniye/İstanbul, Türkiye e-mail: drdede75@hotmail.com 


\title{
Acute Kidney Injury Associated with SARS-CoV-2
}

\begin{abstract}
The novel coronavirus (COVID-19), which erupted in China at the end of 2019, resulted in a global outbreak in a very short time. Although COVID-19 infection mainly affects the respiratory system, renal impairment is common in patients with severe lung involvement and in patients at high risk groups, such as advanced age, diabetes mellitus, hypertension, cardiovascular disease, and chronic kidney disease (CKD). Acute kidney injury (AKI) is one of the major complications of COVID-19 infection and more common in people with CKD which is associated with increased morbidity and mortality. The risk of permanent kidney damage is increased in cases with AKI. It is very important to check and closely monitoring renal functions among this pandemic COVID-19 infection, does not have an absolute treatment. In this review, kidney involvement and acute kidney injury that may develop during the course of COVID-19 are discussed.
\end{abstract}

Keywords: COVID-19, acute kidney injury, kidney functions.

\section{GíRiş}

Bir RNA virüsü olan Coronavirusler (CoV), halk sağlığını tehdit eden, salgınlara neden olabilen ve insanda esas olarak respiratuar sistem tutulumu ile karakterize patojenlerdir. Coronavirüs ailesi geniş bir familya olup bundan önceki yıllarda adını iki salgın ile duyurmuşlardır: 2003 yılında Severe Acute Respiratory Syndrome (SARS-CoV) ve Eylül 2012 tarihinde Middle East Respiratory Syndrome (MERS-CoV) ${ }^{1}$. CoV'lerin insanlarda bulunan, insandan insana kolaylıkla bulaşabilen çeşitli alt tipleri çoğunlukla soğuk algınlığına sendromlarına sebep olurlar. Aralık 2019'da Çin'in Wuhan kentinde etiyolojisi bilinmeyen pnömoni vakalarının bildirimi sonrası Ocak 2020 'de etken olarak yeni bir tip CoV (SARSCoV-2) tanımlanması ile sonuçlanmış ve hastalığının adı COVID-19 olarak kabul edilmiştir1-4. Günümüzde, COVID-19 dünya çapında yayılmış, hemen tüm ülkeler etkilenmiştir ve artık Dünya Sağllk Örgütü tarafından pandemi olarak kabul edilmiştir ${ }^{3,4}$.

SARS-CoV-2'nin kökeni henüz net olmamakla birlikte esas olarak vahşi hayvanlardan kaynaklandığı ve grip virüsüne benzer şekilde damlacık infeksiyonu ve bulaşlı materyalin mukozalara temas ile bulaştığı rapor edilmektedir ${ }^{3}$. Hastalık yaygın olarak halsizlik, ateş, boğaz ağrısı, kuru öksürük ve nefes darlığı gibi semptomlarla kendini belli etmektedir.
Etkilenen hastalarda ölümle sonuçlanan ağır akut solunum yolu infeksiyonu, pnömoni, akut böbrek yetmezliği ve çoklu organ yetmezliği gelişir2-4. Dünya Sağlık Örgütüne (DSÖ) göre ölüm oranı takriben $\% 3,4$ olup birçok faktörden etkilenebilir 4 . İleri yaș, hipertansiyon, diyabet, kardiyovasküler hastalıklar, Kronik Obstrüktif Akciğer Hastalığı (KOAH), kronik böbrek hastalığı (KBH), immünsupresif tedavi, organ nakilli hastalar yüksek risk grubunu oluştururlar ve bu hastalarda mortalite yüksektir. Güncel veriler mortalite ile ilişkili en slk risk grubu hipertansiyon olduğu rapor edilmektedir, birçok olguda da birden çok risk grubu bulunmaktadır ${ }^{4,5}$. Bir meta-analizde ilginç olarak KBH, KOAH'tan yüksek mortal seyrettiği bildirilmiştir6. Ancak Covid-19 pandemisi etkilenen ülkelerin sağlık sistemi, sağlık hizmetlerine erişilebilirlik ve sosyoekonomik durum bu konuda önemli faktörler olarak değerlendirilmektedir ${ }^{7,8}$. Ölümcül seyreden olguların çoğunda başlıca akut böbrek hasarı $(\mathrm{ABH})$ olmak üzere böbrek komplikasyonları gelişmektedir.

\section{COVID-19 ve Akut Böbrek Hasarı}

Yaygin alveolar hasar ve akut solunum yetmezliği (Acute Respiratory Distress Syndrome; ARDS) COVID-19'un ana özellikleri olmasına karşın çoklu organ tutulumunun kaçınılmaz olarak geliştiği, etkilenen hastalarda kardiyovasküler sistem, sindirim sistemi, sinir 
sistemi ve böbrekler dahil olmak üzere çoklu organlarda işlev bozukluğuna maruz bıraktığı bilinmektedir. SARS-CoV hastalarında ABH sık gelişmektedir ve böbrek yetmezliği gelişen hastaların yaklaşık \%92'si ölümcül seyretmektedir. $\mathrm{Bu}$ nedenle $\mathrm{ABH}$, özellikle hastanede yatan hastalarda ölümcül bir SARS komplikasyonu olarak tanımlanmıştır ${ }^{9}$. Benzer şekilde, SARS-CoV-2 olgularında da böbrek yetmezliği mortalitenin majör öncüllerinden olabileceği, SARS-CoV göre SARS-CoV-2 ile infekte olan bireylerde daha sik $\mathrm{ABH}$ gelişebilmektedir ${ }^{7}$.

Genel popülasyonda hastaneye yatırılan hastaların \%3,2-21'inde ve yoğun bakım ünitelerinde \%35-50'inde akut böbrek hasarı geliştiği bilinmektedir ${ }^{10}$. Makalenin yayına hazırlandığı Mayıs 2020 döneminde COVID-19 infeksiyonu ile ilişkili basılmış veri mevcut değildi. Ancak COVID-19 pandemisinin başladığı Çin kaynaklı yayınlarda çeşitli serilerde \%3-13,1 arasında siklık bildirilmektedir ${ }^{11-16}$. Karşıt olarak bir çalışmada COVID-19 ile ilişkili ABH sıklığında bir atış gözlenmediği, SARS-CoV-2 infeksiyonun ABH ile ilişkili olmadığı ve $\mathrm{KBH}$ agreve etmediği iddia edilmiştir ${ }^{17}$. Bununla birlikte, birçok klinisyen COVID-19 infeksiyonu ile ilişkili $\mathrm{ABH}$ insidansının \%5'ten az olamayacağını, olguların yaklaşık \%25-30'unun orta-ağır ABH - Evre 2 veya 3 - oluşabileceğini düşünmektedirler ve tüm olguların yaklaşık \%5-10'unda renal replasman tedavisine ihtiyaç duyacaklarını kanisindadirlar (Tablo 1).

Tablo I: Muhtelif çalışmalarda akut böbrek hasarı sıklığı

\begin{tabular}{|l|}
\hline Yazar Olgu Sayısı (n) ABH (\%) \\
Huang ve ark. ${ }^{[11]} 413(7,3)$ \\
Chen ve ark. ${ }^{[12]} 993(3)$ \\
Wang ve ark. ${ }^{[13]} 1385(3,6)$ \\
Cheng ve ark. ${ }^{[14]} 70136(5,1)$ \\
Shi ve ark. ${ }^{[15]} 827(8,5)$ \\
Wang ve ark. $[16] 10714(13,1)$ \\
\hline
\end{tabular}

Çalışmalar, SARS-CoV-2 infeksiyonunun majör komplikasyonlarından biri akut böbrek yetmezliği olduğunu göstermiş, böbrek yetmezliği özellikle hospitalize hastalarda sık görülmekte olup hastane içi artmış mortalite ile ilişkilidir ${ }^{14,18}$. Böbrek fonksiyonları bozuk olanlarda hem COVID-19 gelişme hem de akut böbrek yetmezliği tablosunun kronik böbrek hastalığı üzerine eklenme potansiyeli riski artmıştır $^{5}$. Geniş ölçekli bir kohortta hastanede kaldıkları süre boyunca olguların \%40'ında anormal böbrek fonksiyonları kanıtı, \%13'ün üzerinde serum kreatinin ve BUN değerlerinde yükselme, \%5,1 $\mathrm{ABH}$ saptanmış ve daha da önemlisi çarpıcı bir şekilde, böbrek hastalığının varlığı artmış hastane içi mortalite ile ilişkili bulunmuștur ${ }^{19}$. Li ve ark yaptıkları bir çalışmada ise kronik hastalığı olan ve $\mathrm{ABH}$ gelişen COVID-19 hastalarının $\mathrm{ABH}$ gelişmeyenlere göre mortalitenin çok daha yüksek olduğunu gösterdiler (mortalite riski: 5.3 vs $~ 1.5$ kat) ${ }^{18}$.

Klinik gözlemler hastaneye yatırılan COVID19'li hastalarında sıklıkla böbrek fonksiyon bozuklukları görüldügünü ortaya koymuştur. Erken dönemde herhangi bir patolojik bulgusu olmayan hastaların bir kismında hastanede izlem sırasında böbrek fonksiyonlarında bozulmalar meydana gelebilmektedir. Başlangıçta hafif anormallikler olarak ortaya çıkan böbrek bozuklukları, daha sonra hastaların önemli bir kısmında ciddi ABH olarak teşhis edilebilir. Chu ve ark hastaların \%6,7'sinde COVID-19 infeksiyonunun başlangıcından ortalama 20 gün sonra böbrek yetmezliği geliştiğini gösterdiler ${ }^{9}$. Akut böbrek yetmezliği tablosu klinik olarak tam gelişmeden önce en yaygın idrar bulgusu hematüri ve albuminürinin dominant olduğu proteinüri saptanır. Bir çalışmada başvuru anında olguların \%44'ünde proteinüri, \%26,9'unda hematüri ve \%14,1 BUN ve \%15,5 kreatinin artışı saptanmıştır. Çalışma sırasında olguların \%3,2'si ilk günlerde $\mathrm{ABH}$ saptanmıştır ${ }^{14}$. 
Çalışmadaki bu son veri COVID-19 olan hastalarda akut böbrek hasarını önlemek için uygun hemodinamik destek ve nefrotoksik ilaçlardan sakınılması gibi erken müdahalelere duyulan ihtiyacı vurgulaması açısından önemlidir. Erken böbrek hasarı insidansının değerlendiren Hong ve ark anlamlı BUN ve kreatinin yüksekliği olmayan hastalarda erken dönemde tahmini glomeruler filtrasyon hizı (eGFH) $(\% 66,7)$, kreatinin klirensi $(\% 41,7)$ ve mikroalbuminüri $(\% 41,7)$ düzeylerinde anormallik olduğunu gösterdiler ${ }^{20}$. COVID-19'lu olgular hastaneye yattıkları sürede, başlangıçta normal böbrek fonksiyonu olanların yaklaşık 1/3'ünde böbrek fonksiyonlarında bozulmalar meydana gelebilmektedir, bunların yaklaşık 1/4'ünde hasta taburcu olurken bile böbrek fonksiyonları bozuktur7. SARS-CoV-2 ilişkili $\mathrm{ABH}$, tipik böbrek yetmezliği hastalarında görülmeyecek şiddette hiperkalemi, hiperfosfatemi ve derin metabolik asidozun eşlik ettiği ağır bir katabolik tablo ile karşılaşılabilmektedir. Ayrıca çok hızlı yükselen BUN ve kreatinin değerleri saptanabilir, bu olgular daha kötü bir prognoza sahiptirler (mortalite, çok yüksek kreatinin seviyeleri olan olgular, ılıman yüksek olanlara göre yaklaşık 2 kat daha fazladır) ${ }^{7}$. Bir başka çalışmada ise ciddi COVID-19 vakalarında proteinüri ile birlikte idrar glukoz düzeyi sağlıklı kontrolden yüksek bulunmuş, hastalığın şiddetini belirlemede bir belirteç olabileceği bildirilmiştir ${ }^{21}$.

Böbrek yetmezliği özellikle komorbiditesi olan olgularda yaşamı tehdit eden komplikasyonlarla ilişkili olduğu için COVID19'lu tüm hastaların böbrek fonksiyonlarının yakından izlemi gerekmektedir. Ayrıca ABH tanısı geleneksel olarak KDIGO kriterlerine göre dayanmaktadır ve birçok merkez esas olarak serum kreatinin düzeyindeki akut değişikliklerini ölçüt almaktadır. Ancak sadece serum kreatinin baz alındığında tanı duyarlılığı $\% 72$ 'den \%4,3'e kadar düşebileceğinden idrar outputu gibi basit bir kriter kullanılarak bu duyarlılık artırılabilir ve/veya sık ölçümler de erken ve doğru teşhis olanağı sağlamaktadır ${ }^{14}$. $\mathrm{Bu}$ nedenle, böbrek hasarının erken tespitini iyileștirmek için COVID-19 hastalarına daha sık serum kreatinin ölçümleri yanı sıra günlük idrar çıkışı izlemi yapılmalıdır.

\section{Akut Böbrek Hasarının Oluşma Mekanizmaları}

COVID-19'lu hastalarda böbrek hastalığı tutulumunun nasıl ve hangi mekanizmalarla geliştiği tam olarak bilinmemektedir. Mevcut bilgi ve veriler hadisenin multifaktör olabileceğini düşündürmektedir. Öncellikle SARS-CoV virüsü fragmanlarının PCR ile hem kanda hem de böbrekte birikimlerinin gösterilmiş olması ${ }^{22}$, benzer şekilde COVID-19 fragmanlarının da aynı yöntemlerle saptanması $^{23}$ bu virüslerin sitopatik etkilerini göstermektedir. Yeni koronavirüsün hücrelere giriş reseptörü olarak SARS-CoV gibi yüksek afinitesi nedeniyle angiotensin-converting enzyme 2 (ACE2) kullandığı ve bu reseptörün böbrek dokusunda akciğerlere kıyasla yaklaşık 100 kat daha potent olduğu ve bu reseptörün yüksek oranlarda ekspresyonu hücresel duyarlılığı artırarak rol oynayabileceği iddia edilmiştir. ABH ve kardiyak hasar COVID-19'un en sık bildirilen komorbiditeleri olduğu bilgisi SARS-CoV-2'nin bu organlar için tropizme sahip olabileceğini düşündürmektedir ${ }^{24}$. COVID-19'a bağlı renal proksimal tübül hücreleri ve podositlerde meydana gelen sitotoksik etki ve renal hasarın ACE2 bağımlı reseptörler ve kofaktör olarak hücresel transmembran serin proteaz (TMPRSSs) kanalıyla olması olasıdır2426. Çalışmalar yüksek düzeylerde ACE2 eksprese eden proksimal tübül hücrelerinde aktif SARS$\mathrm{CoV}$ replikasyonu ile indüklenemediği postmortem verilerle gösterilmesi böbrek yetmezliğinin bu mekanizma ile geliştiğini desteklememektedir ${ }^{9,24}$.

Viral antijen ile ilişkili immün komplekslerin veya virüsün direkt olarak neden olduğu spesifik immünolojik efektör mekanizmaların 
(spesifik $\mathrm{T}$ hücre lenfosit veya antikoru) birikmesi kollapsing glomeruler nefrite yol açarak böbreğe zarar verebilir ${ }^{16}$. Ancak SARS hastalarından alınan böbrek spesmenlerin incelenmesinde işık mikroskobunda normal glomerüler bir görünüm ve elektron mikroskobik incelemede dens depozidlerin görülmemesi aktif bir immün aracılı glomerülonefriti desteklememektedir ${ }^{9}$. Karşıt olarak Diao ve ark yaptıkları çalışmada SARSCoV-2 için insan böbreklerinin spesifik bir hedef olabileceğini, postmortem böbrekte virüs ile direkt olarak infekte ettiğini ve bu etkinin de diğer SARS-CoV'dan farklı olarak SARS-CoV2'nin ACE2 tropizmi nedeniyle olabileceğini belirtmişler ${ }^{28}$. Etkinin hem $\mathrm{ABH}$ oluşumunu başlatabileceği hem de böbreklerin rezervuar işlevi görüp viral diseminasyona yol açabileceği düşündürmektedir.

ARDS patogenezinde yer alan sitokin firtınası sendromu ve SARS-CoV infeksiyonu sirasinda çoklu organ yetmezliği, anormal büyüklükte inflamatuar reaksiyonla ilişkili olduğu bildirilmiştir ${ }^{1,9}$. SARS-CoV-2 infeksiyonu, proinflamatuar sitokinleri (IL-4, IL-10, IL-1b, IFN-c, IP-10 ve MCP-1) ve kemokinleri (CCL2, CCL3, CCL5) salarak sitokin kaskadını aktive eder ${ }^{23}$. $\mathrm{Bu}$ tür hastalarda doğuştan gelen ve adaptif bağışıklık hücresi popülasyonlarında fonksiyonel defektler proinflamatuar bir sürece neden olmaktadır. Yoğun pro-inflamatuar sitokinlerin meydana getirdiği immünolojik hasar böbrekler dahil hedef organlarda hücre hasarını indüklemektedir ${ }^{29}$. Sitokin aracılı inflamatuar $\mathrm{ABH}$, çeşitli immünolojik tedavi modaliteleri uygulan kanser hastaları ve timoglobulin verilen renal transplant hastaları gibi birçok klinik durumda rapor edilmiştir ${ }^{30}$. $\mathrm{Bu}$ patolojik süreç hastaların ölümü ile sonuçlanabilmektedir. $\mathrm{Bu}$ verilere rağmen sitokin firtınası sendromunun SARS'ta olduğu gibi ABH'na yol açan SARS-CoV-2 infeksiyonunun bir özelliği olup olmadığı açık değildir.
Ayrıca, COVID-19 hastalarında böbrek yetmezliği küçük damar vaskülitleri, trombus, hipoksi, şok, rabdomiyoliz, ve dehidrasyon gibi genel olarak akut böbrek hasarı yapan nedenler ile altta yatan hastalıkların varlı̆̆ı ve steroidal olmayan anti-inflamatuar gibi ilaçların yanlış kullanımı nedeniyle meydana gelebilir. COVID19'lu hastalarda mikrotrombus oluşumu alakalı kanıtlar bulunmaktadır. Mikrotrombus akut iskemiye ve akut böbrek hasarına neden olabilir ${ }^{31}$.

COVID-19 infeksiyonun renal tutulum tanısı standart tanı yöntemlerine dayanır. COVID-19 olası vaka tanımına uyan hastalarda solunum yolu numuneleri SARS-CoV-2 olgularının rutin doğrulaması gerçek-zamanlı reverse transkripsiyon polimeraz zincir reaksiyonu (rRT-PCR) testi ile virus RNA'sının özgül dizilerinin saptanması ve gerekli olduğunda nükleik asit dizi analizi yöntemi ile doğrulanması temeline dayanmaktadır. Bir veya daha fazla negatif sonuç ile COVID-19 virus infeksiyonu olasılığı dışlanamaz. rRT-PCR testlerinin negatif olduğu ve COVID-19 infeksiyonu ile kuvvetli epidemiyolojik ilişkisi olan olgularda akut ve/veya konvalesan fazda alınan serum örneklerinde serolojik testlerin çalışılması tanıyı destekleyebilir. Bu amaçla ELISA ya da IgM/IgG saptayan hızlı antikor testleri gibi serolojik testler kullanılmaktadır ${ }^{32}$. Tanısal örnekleme için idrarın kullanılması uygun görünmemektedir. 19 vakanın orofaringeal sürüntü, kan, idrar ve dișkı örneklemenin yapıldığı bir çalışmada rRT-PCR testi ile yapılan hiçbir olgunun idrar örneklemesinde pozitif sonuç tespit edilmemiștir33.

Şekil 1'de COVID-19 infeksiyonu ile ilişkili ABH nedenleri şematize edilmiştir. 


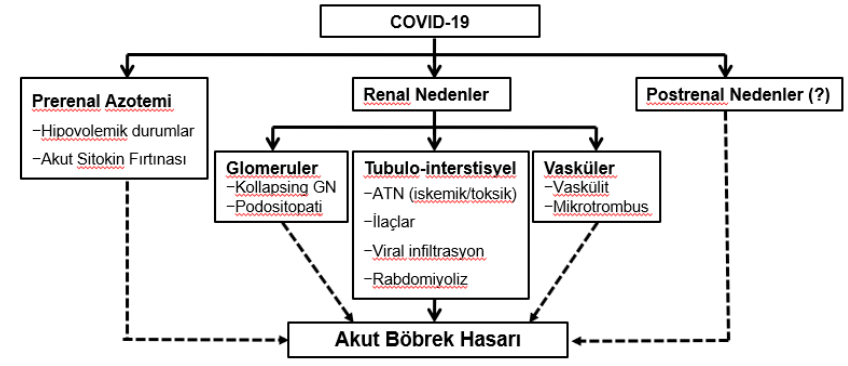

Şekil 1: COVID-19 seyri sırasında akut böbrek hasarı gelişme nedenleri

Akut Böbrek Hasarının Önlenmesi ve Tedavisi

COVID-19 tanısı alan hastalar öncellikle ABH açısından riskli grup olarak değerlendirilmeli, mümkün olan en kısa zamanda destekleyici tedavi başlanmalı, nefrotoksisiteden sakınılmalı, kontrastlı görüntüleme yöntemleri mutlak endikasyon dışında çekilmemelidir. COVID-19'dan etkilenen insanlar için tüm rutin önlemler, mevcut bilgiler değişene kadar akut böbrek yetmezliği olan COVID-19 hastaları için de uygulanabilir ve $A B H$ gelişenlerde destekleyici tedavi COVID-19 olmayan hastalarda gelişen böbrek yetmezliği ile benzerdir. Ancak bu olgularda metabolik parametrelerin hızla kötüleşebileceği öngörülerek yakın izleme alınmalıdır. Özellikle ağır inflamatuar reaksiyonları veya sitokin fırtınası olanlar için ve konservatif tedavi ile düzelmeyen hipervolemi, metabolik asidoz, hiperkalemi, üremik ensefalopati ve üremik perikardit gibi manifestasyonlar meydana geldiğinde renal replasman tedavisi başlatılmalıdır $7,10,18,25$.

Şüphesiz, SARS-CoV-2'yi doğrudan hedefleyen ilaçlar COVID-19 için en etkili tedaviler olacaktır. Ancak günümüzde COVID-19 için güvenilirliği ve etkinliği kanıtlanmış spesifik bir tedavi bulunmamaktadır. COVID-19 hastalarını sadece antiviral etkiler için değil, aynı zamanda akut böbrek yetmezliği de dahil olmak üzere diğer semptomlar için tedavi etmek için onaylanmış bir ilaç yoktur. Bu hastaları tedavi etmek için etkinliği kanıtlanmış bir antiviral ilaç olmamasına rağmen durumun aciliyeti ve bilimsel verilerin kısıtlılığı nedeniyle, etkili olabileceği yönünde sınırlı da olsa veri bulunan tedavi seçenekleri, hayati organların işlevini sürdürmek için antiviral ilaçların başlatılması önerilmektedir; bu nedenle kritik hastalar arasında morbidite ve mortaliteyi azaltabilir. Akut böbrek yetmezliği COVID-19 infeksiyonunda prognostik bir faktördür ve COVID-19 geliştikten sonra ortaya çlktığı düşünüldügüunde direkt COVID-19 hastalığının tedavisinin $\mathrm{ABH}$ için de yararlı olduğu düşünülebilir18,25. Virüs 'spike' glikoproteinleri, proteaz TMPRSS2 ve ACE2 reseptörünü hedefleyen ajanlar, önleme ve tedavi için potansiyel klinik stratejiler olarak ortaya çıkmaktadır ${ }^{24}$.

Semptomatik olan tüm COVID-19 hastalarına antimalaryal ilaç olan hidroksiklorokin başlanması önerilmektedir ${ }^{34-36}$. Hidroksiklorokinin böbrek fonksiyonları üzerindeki etkileri açık olmamakla birlikte, çok merkezli çalışmalarda yeterli güvenlikte göstermiş olduğu sistemik antiviral etkilerinin böbrek fonksiyonlarını da olumlu etkileyebileceği düșünülmektedir. Hidroksiklorokin, viral partiküllerin hücresel hücre reseptörlerine bağlanmasıyla viral siklusun tamamlanmasını dolayısıyla viral replikasyonu engeller ve hücre içi düzeyde endozomda COVID-19 infeksiyonuna bağlı meydana gelen asidik pH'yı düzelterek infeksiyonu inhibe ederek güçlü bir antiviral etki gösterebileceği öne sürülmüştür ${ }^{36}$. Bu ilacın bazı ekollere göre mortaliteyi arttırabileceğine ilişkin kaygllara rağmen çok merkezli bir çalışmada klorokin fosfatın koronavirüslere karşı kabul edilebilir antiviral etkilere sahip olduğunu, tedavi şansını arttırdığını hastanede kalış süresini kısalttığını bildirilmiştir ${ }^{37}$.

COVID-19 infeksiyonun akciğerlerde yoğun lokalizasyon gösteren ACE2 reseptörlerinin infeksiyonun ARDS gibi ağır formlarının patogenezindeki tanımlayıcı rolü ve bu yolağın aktivasyonun koruyucu olabileceği görüşü 
tedavi için potansiyel stratejilerden biri olarak düşünülmüştür. Ayrıca, renin-anjiyotensinaldosteron sistemi (RAAS) inhibitörleri COVID19'da faydalı olabilir. Losartan gibi anjiyotensin reseptör blokerlerinin (ARB) ilaçların akciğer başta olmak üzere birçok dokuda bu reseptörleri arttırdıkları bilinmektedir ${ }^{38}$. Kimi deneysel veriler rekombinant ARB'ler tarafindan ACE2 reseptörünün upregülasyonu SARS-CoV-2 infeksiyonu sirasinda koruyucu olabileceği öne sürülmüştür ${ }^{39}$. Ancak bu etkinin COVID-19 infeksiyonundaki sonuçları doğrulanmaya muhtaçtır. Ancak bu düşünce diyabet ve hipertansiyonu olan COVID-19 hastalarında ACE inhibitörü veya ARB kullanıp kullanmamak konusunda başka bir endişeyi beraberinde getirmektedir. Avrupa Hipertansiyon Cemiyetinin COVID-19 riski altında olan veya COVID-19 tanısı konmuş hastalarda bu ilaçların kullanımı konusunda mümkün olduğunca konservatif yaklaşım önermesi bu endişenin yersiz olmadığını göstermektedir ${ }^{40}$. Ancak bir çalışmada hastanede yatan hipertansiyonlu COVID-19 hastalarında, ACEI/ARB'nin kullanan hastaların kullanmayanlara kıyasla tüm nedenlere bağlı mortalitenin daha düşük bulunmuş ve bu ilaçları hastane içi kullanımının artmış mortalite riski ile ilişkili bulunmamıştır ${ }^{24,41}$. Bu nedenle COVID-19 hastalarında bu ilaçların kesilmesi potansiyel olarak zararlı olabilir. Sonuç olarak ACE2 viral invazyon için gerekli olsa da, ACE inhibitörlerinin veya ARB ilaçların prognozu kötüleştirdiğine dair bir kanıt yoktur.

Klinik olarak kanıtlanmış bir TMPRSS2 inhibitörü olan Camostat mesilat adı verilen ilaç SARS-CoV-2'nin hücre girişini önler ve COVID19 için bir tedavi seçeneği oluşturabilir ${ }^{42}$.

Hiperinflamatuvar yanıta bağlı gelişen sitokin fırtınası sendromu ile karakterize makrofaj aktivasyon sendromu gelișen ARDS olgularında anti-sitokin tedavilerden yararlanabildiği bildirilmiştir. Sınırlı veri bulunmasına rağmen şimdiye kadar sitokin firtınası sendromunun ana itici gücü olarak gösterilen IL-6 inhibisyonu tedavi denenmiş, bu amaçla spesifik bir AntiIL6R olan Tosilizumab şiddetli COVID-19 vakalarında faydalı olduğu görülmüştür ${ }^{24,43}$. Anti-IL6R etkisi olan monoklonal tosilizumab antikoru gibi tedavilerin kendisinin de ARDS'ye neden olabileceğine dair veriler de mevcuttur ${ }^{43}$.

COVID-19 tedavisi için umut verici bir seçenek olarak önerilen favipiravir, lopinavir, ritonavir, remdesevir gibi antiviral tedaviler COVID-19 infeksiyonunu kontrol etme, progresyonunu durdurma, hastanede kalış sürecini azaltma, ölümcül komplikasyonu önleme ve mortalite azaltma üzerinde etkili olabileceklerine dair veriler her geçen gün artmaktadır. Ayrıca immün plazma tedavileri, plazmaferez, statinler gibi anti-inflamatuar tedavi seçenekleri sınırlı vakalarda denenmiş, bazı olumlu raporlar bildirilmiş olmakla birlikte bu tarz tedaviler, geniş ölçekli, kontrollü ve prospektif çalışmalarla doğrulanmayı beklemektedir ${ }^{32}$.

\section{SONUÇ}

SARS-CoV-2 virüsü böbrek dahil çoklu organ komplikasyonlarına neden olmaktadır. COVID19 infeksiyonu özellikle hastanede yatan hastalarda akut böbrek hasarı sıklıkla gelişebilmektedir, bu durum morbidite ve hastane içi mortaliteyi önemli ölçüde arttırmaktadır. Ayrıca kalıcı sekel olarak kalabilmektedir. Kreatinin, kan üre azotu, proteinüri ve hematüriyi başvuru sırasında kontrol etmek önemlidir. Hastaneye yatan hastalarda ve özellikle ağır pnömoni ve ARDS olan hastalarda sık aralıklarla böbrek fonksiyonları izlenmelidir. Hastaların böbrek fonksiyonlarının yakından izlenmesi, nefrotoksinlerden kaçınma ve böbreklere potansiyel olarak zarar verebilecek çalışmaların ve müdahalelerin en aza indirilmesi özellikle önemlidir. Kanıtlanmış bir tedavi rejiminin olmaması nedeniyle ağır COVID 19 infeksiyonu geçiren akut böbrek hasarı dahil multiorgan yetmezliği gelişen hastalara agresif destekleyici tedavi ve önlemlere ihtiyaç vardır. ACE 
inhibitörleri ve ARB kullanımı varsa, devam edilmesi önerilir. Klinisyenlerin şiddetli COVID19 olan hastalarda gelişebilecek böbrek hasarı açısından dikkatli olmaları gerekir.

Etik Hususlar: Etik konular (intihal, veri üretimi, çift yayın dahil) yazarlar tarafından kontrol edilmiştir.

Çıkar Çatışması Beyanı: Yazarlar çıkar çatışması olmadığını bildirmişlerdir.

Finansal Destek: Bu çalışma her hangi bir fon tarafından desteklenmemiștir.

Declaration of Conflicting Interests: The authors declare that they have no conflict of interest.

Financial Disclosure: No financial support was received.

\section{KAYNAKLAR}

1. deWit E, van Doremalen N, Falzarano D, Munster VJ. SARS and MERS: Recent insights into emerging coronaviruses. Nat Rev Microbiol. 2016; 14: 523-34.

2. Lu H, Stratton CW, Tang YW. Outbreak of pneumonia of unknown etiology in Wuhan China: The mystery and themiracle. J Med Virol. 2020; 92: 401-2.

3. Hui DS, Azhar IE, Madani TA, et al. The continuing 2019-nCoV epidemic threat of novel coronaviruses to global health -The latest 2019 novel coronavirus outbreak in Wuhan, China. Int J Infect Dis. 2020; 91: 264-6.

4. World Health Organization DirectorGeneral's opening remarks at the media briefing on COVID-19. WHO; 3 March 2020.

5. Emami A, Javanmardi F, Pirbonyeh N, Akbari A. Prevalence of Underlying Diseases in Hospitalized Patients with COVID-19: a Systematic Review and Meta-Analysis. Arch Acad Emerg Med. 2020; 24; 8: e35. eCollection 2020.
6. Zhao X, Zhang B, Li P, et al. Incidence, clinical characteristic and prognostic factor of patients with COVID-19: a systematic review and metaanalysis. medRxiv. 2020. doi: https://doi.org/10.1101/2020.03.17.2003757 2

7. Lotfi B, Farshid S, Dadashzadeh N, Valizadeh $\mathrm{R}$, Rahimi MM. Is Coronavirus Disease 2019 (COVID-19) Associated with Renal Involvement? A Review of Century Infection, Jundishapur J Microbiol. 2020; 13: e102899. doi: 10.5812/jjm.102899.

8. Ji Y, Ma Z, Peppelenbosch MP, Pan Q. Potential association between COVID-19 mortality and health-care resource availability. Lancet Glob Health. 2020; 8. e480. doi: 10.1016/S2214109X(20)30068-1.

9. Chu KH, Tsang WK, Tang CS, et al. Acute renal impairment in coronavirus-associated severe acute respiratory syndrome. Kidney Int. 2005; 67: 698-705.

10. Koza Y. Acute kidney injury: current concepts and new insights. J Inj Violence Res. 2016; 8: 58-62.

11. Huang C, Wang Y, Li X, et al. Clinical features of patients infected with 2019 novel coronavirus in Wuhan, China. Lancet. 2020; 395: 497-506.

12. Chen N, Zhou M, Dong $\mathrm{X}$, et al. Epidemiological and clinical characteristics of 99 cases of 2019 novel coronavirus pneumonia in Wuhan, China: a descriptive study. Lancet. 2020; 395: 507-13.

13. Wang D, Hu B, Hu C, et al. Clinical characteristics of 138 hospitalized patients with 2019 novel coronavirus-infected pneumonia in Wuhan, China. JAMA. 2020; 323: 1061-9.

14. Cheng Y, Luo R, Wang $\mathrm{K}$, et al. Kidney disease is associated with in-hospital death of patients with COVID-19. Kidney Int. 2020; 97: 829-38. 
15. Shi S, Qin M, Shen B, et al. Association of Cardiac Injury With Mortality in Hospitalized Patients With COVID-19 in Wuhan, China. JAMA Cardiol. 2020 Mar 25. doi: 10.1001/jamacardio.2020.0950.

16. Wang D, Yin Y, Hu C, et al. Clinical course and outcome of 107 patients infected with the novel coronavirus, SARS-CoV-2, discharged from two hospitals in Wuhan, China. Crit Care. 2020; 24 : 188. doi: 10.1186/s13054-020-02895-6.

17. Wang L, Li X, Chen $\mathrm{H}$, et al. Coronavirus Disease 19 Infection. Does Not Result in Acute Kidney Injury: An Analysis of 116 Hospitalized Patients from Wuhan, China. Am J Nephrol. 2020; 51: 343-8.

18. Li Z, Wu M, Yao J, et al. Caution on kidney dysfunctions of 2019-nCoV patients. medRxiv. 2020. doi: 10.1101/2020.02.08.20021212.

19. Naicker S, Yang CW, Hwang SJ, Liu BC, Chen JH, Jha V. The Novel coronavirus 2019 epidemic and kidneys. Kidney Int. 2020; 97: 824-8.

20. Hong Xw, Chi Zp, Liu Gy, et al. Analysis of early renal injury in COVID-19 and diagnostic value of multi-index combined detection. MedRxiv. 10.1101/2020.03.07.20032599.

21. Liu R, Ma $Q$, Han $H$, et al. The value of urine biochemical parameters in the prediction of the severity of coronavirus disease 2019. Clin Chem Lab Med. 2020 Apr 14. pii:/j/cclm.ahead-ofprint/cclm-2020-0220/cclm-2020-0220.xml.

doi: 10.1515/cclm-2020-0220.

22. Peiris JSM, Chu CM, Cheng VCC, et al. Clinical progression and viral load in a community outbreak of coronavirus-associated SARS pneumonia: a prospective study. Lancet. 2003; 361: 1767-72.

23. Huang C, Wang Y, Li X, et al. Clinical features of patients infected with 2019 novel coronavirus in Wuhan, China. Lancet. 2020; 395: 497-506.
24. Perico L, Benigni A, Remuzzi G. Should COVID-19 Concern Nephrologists? Why and to What Extent? The Emerging Impasse of Angiotensin Blockade. Nephron. 2020; 144: 213-21.

25. Yalameha B, Roshan B, Bhaskar LVKS, Mohmoodnia L. Perspectives on the relationship of renal disease and coronavirus disease 2019. J Nephropharmacol. 2020; 9: 1-5.

26. Pan XW, Xu D, Zhang H, Zhou W, Wang LH, Cui XG. Identification of a potential mechanism of acute kidney injury during the COVID-19 outbreak: a study based on single-cell transcriptome analysis. Intensive Care Med. 2020; 1-3.

27. Moeinzadeh F, Dezfouli M, Naimi A, Shahidi S, Moradi H. Newly Diagnosed Glomerulonephritis During COVID-19 Infection Undergoing Immunosuppression Therapy, a Case Report. Iran J Kidney Dis. 2020; 14: 23942.

28. Diao B, Feng Z, Wang C, et al. Human kidney is a target for novel severe acute respiratory syndrome coronavirus 2 (SARS-CoV-2) infection. medRxiv. 2020 Mar; 2020.03.04.20031120.

29. Huang KJ, Su IJ, Theron M, et al. An interferon-gamma-related cytokine storm in SARS patients. JMedVirol. 2005; 75: 185-94.

30. Perazella MA, Shirali AC. Nephrotoxicity of Cancer Immunotherapies: Past, Present and Future. J Am Soc Nephrol. 2018; 29: 2039-52.

31. Ng JJ, Luo Y, Phua K, Choong AMTL. Acute kidney injury in hospitalized patients with coronavirus disease 2019 (COVID-19): Metaanalysis. J Infect. 2020:S0163-4453(20)302802.

32. Iyer M, Jayaramayya K, Subramaniam MD, et al. COVID-19: an update on diagnostic and therapeutic approaches. BMB Rep. 2020; 53: 191-205. 
33. Xie C, Jiang L, Huang G, et al. Comparison of different samples for 2019 novel coronavirus detection by nucleic acid amplification tests. Int J Infect Dis. 2020; 93: 264-7.

34. Gao J, Tian Z, Yang X. Breakthrough: Chloroquine phosphate has shown apparent efficacy in treatment of COVID-19 associated pneumonia in clinical studies. Biosci Trends. 2020; 14: 72-3.

35. Geleris J, Sun Y, Platt J, et al. Observational Study of Hydroxychloroquine in Hospitalized Patients With Covid-19. N Engl J Med. 2020;NEJMoa2012410. doi: 10.1056/NEJMoa2012410.

36. Vincent MJ, Bergeron E, Benjannet S, et al. Chloroquine is a potent inhibitor of SARS coronavirus infection and spread. Virol J. 2005; 2: 69 .

37. Multicenter collaboration group of Department of Science and Technology of Guangdong Province and Health Commission of Guangdong Province for chloroquine in the treatment of novel coronavirus pneumonia. Zhonghua Jie He He Hu Xi Za Zhi. 2020; 43: 185188. doi:10.3760/cma.j.issn.10010939.2020.03.009.

38. Kuba K, Imai Y, Rao S, et al. A crucial role of angiotensin converting enzyme 2 (ACE2) in SARS coronavirus-induced lung injury. Nat Med. 2005; 118: 875-9.
39. Gu H, Xie Z, Li T, et al. Angiotensinconvertingenzyme 2 inhibits lung injury induced by respiratory syncytial virus. Sci Rep. 2016; 6: 19840.

40. ESH Statement on COVID-19 |EuropeanSociety of Hypertension [Internet] [cited 2020 Mar 13]. Available from: https://www.eshonline.org/spotlights/eshstatement-on-covid-19/

41. Zhang P, Zhu L, Cai J, et al. Association of Inpatient Use of Angiotensin Converting Enzyme Inhibitors and Angiotensin II Receptor Blockers with Mortality Among Patients With Hypertension Hospitalized With COVID-19 [published online ahead of print, 2020 Apr 17]. Circ Res. 2020;10.1161/CIRCRESAHA.120.317134. doi:10.1161/CIRCRESAHA.120.317134

42. Hoffmann M, Kleine-Weber H, Schroeder S, et al. SARS-CoV-2 cell entry depends on ACE2 and TMPRSS2 and is blocked by a clinically proven protease inhibitor. Cell. 2020; 181: 27180.

43. Fu B, Xu X, Wei H. Why tocilizumab could be an effective treatment for severe COVID-19? J Transl Med. 2020; 18: 164. Published 2020 Apr 14. doi:10.1186/s12967-020-02339-3 